\title{
GEOTHERMIC STATUS OF THERMOPYLAE - ANTHILI AREA IN FTHIOTIDA PREFECTURE
}

\author{
Metaxas A. ${ }^{1}$, Varvarousis G. ${ }^{1}$, Karydakis Gr. ${ }^{1}$, Dotsika E. ${ }^{2}$, Papanikolaou G. ${ }^{3}$ \\ ${ }^{1}$ Institute of Geology and Mineral Exploration, Entrance C' Olympic Village 13677 Acharnae - Greece \\ ${ }^{2}$ Laboratory of Archaeometry, Institute of Materials Science N.C.S.R "Demokritos", \\ 15310 Aghia Paraskevi - Greece \\ ${ }^{3}$ Geologist, Postgraduate student, Faculty of Geology and Geoenvironment, National \& Kapodistrian \\ University of Athens,geopapgr@gmail.com
}

\begin{abstract}
The purpose of this study was the discovery, identification and evaluation of directly exploitable geothermal fields, in the Thermopylae - Anthili area $\left(100 \mathrm{~km}^{2}\right)$.

After the evaluation and the processing of any preexisting data,followed the surface works, such as further geological mapping, tectonic and stratigraphic correlations and analyses, geothermal impressions, observations at 30 recorded points (springs, drillings, wells) regarding water sampling, chemical analyses, temperature, $\mathrm{pH}$ and conductivity measurements, special sampling for Br and isotopes analyses. The in depth works that took place concern geophysical prospecting, loggings, small and large diameter drillings. All the data were digitized and processed in a GIS environment.

After correlating all the data collected for the region, a geological - geothermal model was constructed. According to this model, water percolates through permeable formations, joints and faults, gets mixed with the existing salt water, warms up and then ascends to the surface through faults and concentrates on proper reservoirs. Specifically, the region of Damasta where two areas of hot water reservoirs have been identified is of particular geothermal interest. The first, located in TriassicJurassic limestones (more than $600 \mathrm{~m}$ deep), presents the greatest interest in terms of temperature and capacity, while the second (found on the surface and up to $350 \mathrm{~m}$ deep) is located in Quaternary sediments and the upper formations of the underlying Late Cretaceous limestone.
\end{abstract}

Key words: geothermy, reservoir, geothermal gradient, isothermal lines, Central Greece.

\section{Introduction}

Geothermy as an alternative form of energy, is sustainable and does not pollute the environment. It should also be mentioned that Greece, according to the European Union standards, has to increase the use of alternative energy sources to $18 \%$ of the total energy consumption by 2020 . Any geothermal energy exploitation will bring social, financial and environmental benefits, in both regional and national level.

A research about the geothermal field of Spercheios area was made to identify if there is any geothermal interest in the geological formations of the basin and then to estimate if there is any ability of these new fields to be exploited. In this framework of the Spercheios basin research (Metaxas 


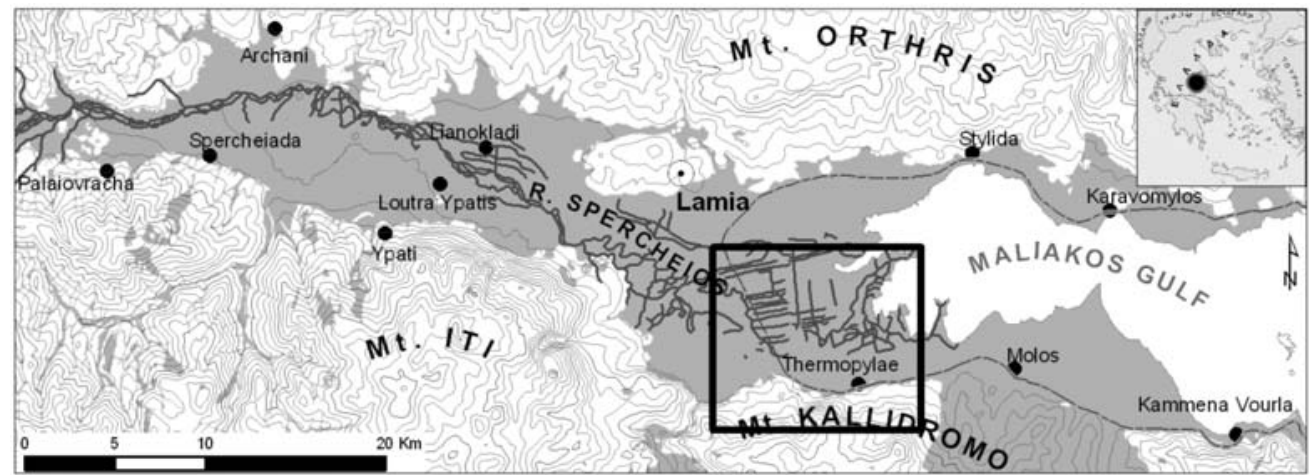

Fig. 1: Indicative map of Spercheios Basin (in black frame the Thermopylae-Anthili area).

et.al., 2008), a significant geothermal field was found near Thermopylae - Anthili, in the close area of Damasta (Fig. 1) that is described below.

Spercheios basin is located in central Greece and in terms of administration belongs to the Fthiotida prefecture , where reside the headquarters of the region of Central Greece. The basin's surface is approximately $700 \mathrm{~km}^{2}$, while of the wider research area is $2400 \mathrm{~km}^{2}$. It ranges from Maliakos bay in the East to Tymfristos mountain on the West. To the North the basin is defined by Mount Orthris and to the South by mountains Iti and Kallidromo (Fig. 1).

Geothermal energy in Spercheios basin has been known since ancient times. For example the Ypati baths are mentioned in inscriptions of the 4th century B.C. and seem to have been dedicated to the goddess Aphrodite. During the Turkish Occupation they were known as "Patratzik Baths".

The only use of geothermal energy so far, is for spa therapy.

\section{Methodology}

After the evaluation and the processing of previous studies (Garagunis, C. N., 1976; Stamatakis, 1987) and any preexisting data, as were the geological mapping (Marinos et al., 1963, 1967) and the recorded temperature measurements of the water samples by surface-active hot springs, drillings and wells (Dounas et.al, 1978), an widespread thermal anomaly was observed in Spercheios that occupies the entire basin and extends beyond it.

The survey in Spercheios basin, determined that the Thermopylae-Anthili area, namely the close area of Damasta presents the greatest geothermal interest. The results of this study is the outcome of numerous surface works in the area such as further geological mapping, tectonic and stratigraphic correlations and analyses, geothermal impressions, observations at 30 recorded points (springs, drillings, wells) regarding water sampling, chemical analyses, temperature, $\mathrm{pH}$ and conductivity measurements, special sampling for $\mathrm{Br}$ and isotopes analyses. The in depth works that took place concern geophysical prospecting, loggings, small and large diameter drillings. All the data were digitized and processed in a GIS environment. After correlating all the data collected for the region, a geological - geothermal model was constructed.

\section{Thermopylae-Anthili area}

The surface warm water events occur along faults in the areas of Kammena Vourla, Thermopylae, Psoroneria, Ypati, Platystomo, Palaiovracha, Archani (Metaxas et al., 2008). 


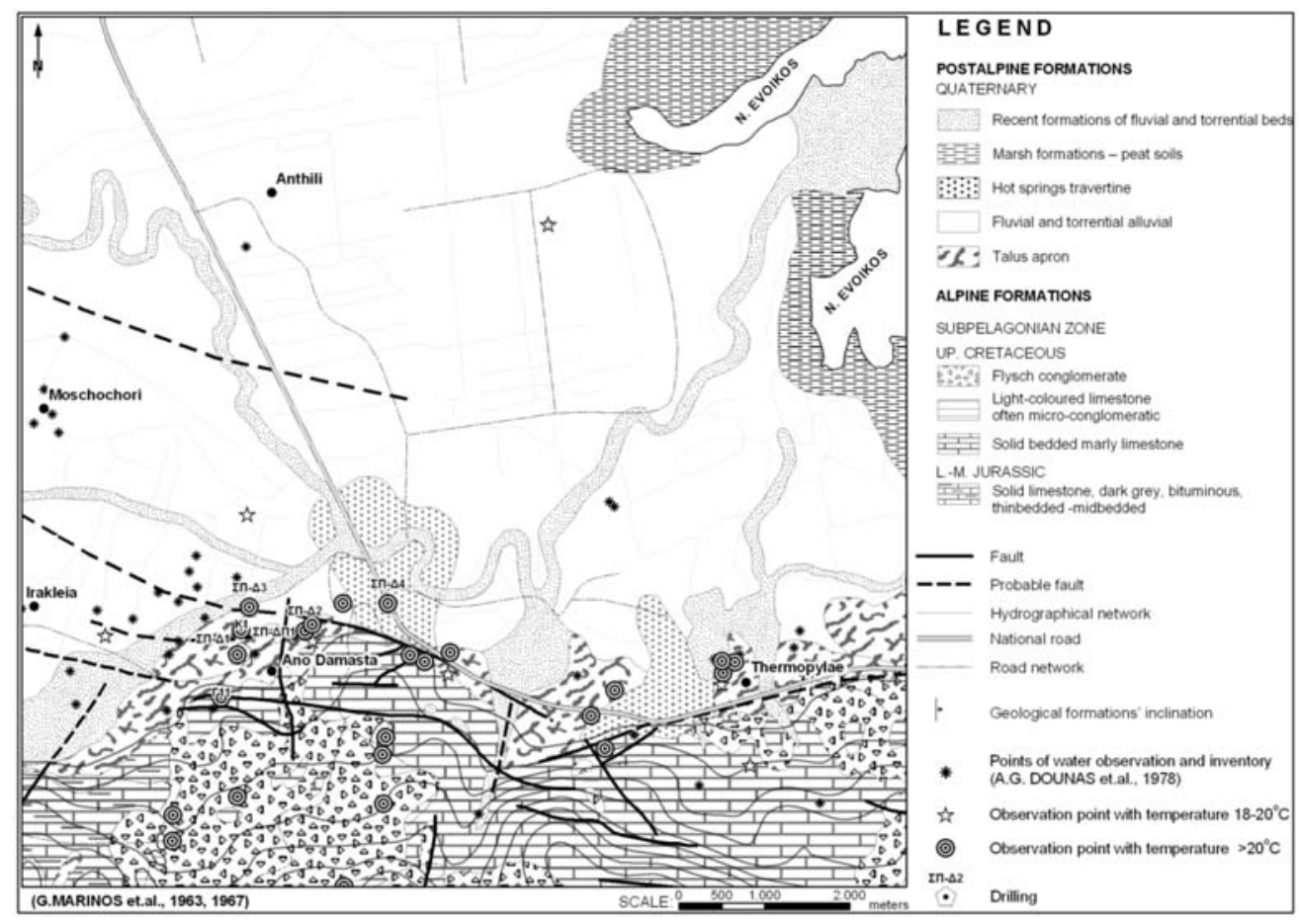

Fig. 2: Geological map of Thermopylae-Anthili area.

The area of Thermopylae - Anthili is located in the southeastern part of the Spercheios basin and covers an area of $100 \mathrm{~km}^{2}$. The synthesis of geological mappings (Fig. 2) indicated that the background consists of flysch and limestones (Upper Cretaceous), parts of the schist-chert formation with ophiolites and limestones (Triassic - Jurassic) of the Subpelagonian zone. The sediments of the area are mainly recent formations of river and torrent beds, older fluvial and torrential deposits, slope debris and hot springs' travertine, mainly in the Thermopylae and Psoroneria areas. In coastal regions, particularly at the mouth of Spercheios river, recent marsh formations with peat are observed. The basin's clastic sediments and the layers of limestone and dolomite are permeable formations and are able to hold significant quantities of geothermal fluids. The impermeable formations of ophiolites and flysch as well as the fine-grained clastic materials, mainly located in the eastern part of the basin, are considered the permeable formations' cap preventing thus any direct heat loss.

The intense tectonics observed in the basin, the vertical faults, the joints and any form of discontinuity, are contributing to the upward movement of hot fluids that reach the surface. Warm water, during its ascent through the faults towards the surface, is mixed with cold water table aquifers, leading to changes in both its temperature and its chemical composition. The temperature across the basin is irregular and significant fluctuation is observed from place to place. The main directions of the region's faults are E-W and NW-SE while the recent ones are vertical to the old ones: NE-SW and N-S.

In Thermopylae-Anthili and namely in the close area of Damasta, were also carried out several small and large diameter drillings (Fig. 2) that were part of this project (Metaxas et al., 2008) in order to determine the geothermal field for immediate use, and its qualitative and quantitative parameters.

Specifically in Damasta, a productive drilling was made and based at its rate $\mathrm{C}=435 \mathrm{~m}^{2} / \mathrm{sec}^{5}$ was 


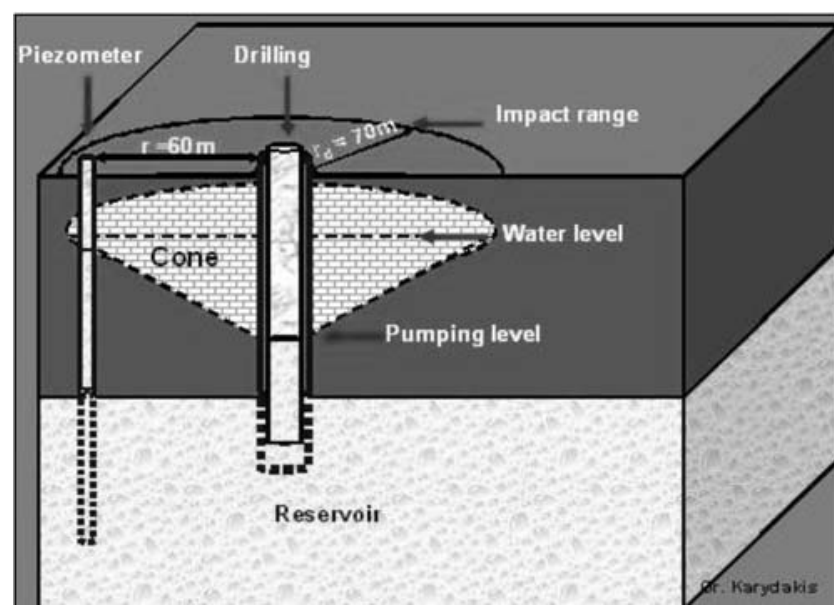

Fig. 3: Impact range $r_{d}$ and drop cone of the drill level.

characterised as efficient, and its specific capacity that is over $40\left(\mathrm{~m}^{3} / \mathrm{h}\right) / \mathrm{m}$ is considered quite good for a constant pumping flow of $115 \mathrm{~m}^{3} / \mathrm{h}$ and a temperature of $43.6^{\circ} \mathrm{C}$. The range of the effect should be considered to be at least $100 \mathrm{~m}$ on a constant supply of $115 \mathrm{~m}^{3} / \mathrm{h}$ (Fig. 3) and the reservoir has a high permeability, is semi-confined and has also a high pressure drop factor.

Observations at 30 recorded points (springs, drillings, wells) showed that temperatures in the area range from $19.4^{\circ} \mathrm{C}$ to $43.6^{\circ} \mathrm{C}$.

The geochemical and isotopic study of the hot water in the Thermopylae - Anthili region (Dotsika et. al. 2008), showed that according to the concentration of the total dissolved solids (TDS), it is classified as salt water, with greater concentration in Psoroneria area (Damasta). In terms of acidity ( $\mathrm{pH}$ ) the water is neutral to slightly alkaline (Psoroneria) and according to the Waterlot chart, the potability is not appropriate. From the Piper chart it seems that warm water is sodic, chloride, sea water and comes from calcareous and siliceous rocks.

The ionic values of the water (Dotsika et. al. 2008) show that the solutions are chemically charged, with the concentration of the chlorine salt at $16000 \mathrm{mg} / \mathrm{L}$. The water specimens from the region of Thermopylae are of $\mathrm{Na}-\mathrm{Cl}, \mathrm{Na}-\mathrm{HCO}_{3}$ and $\mathrm{Ca}-\mathrm{HCO}_{3}$ type.

The use of silica geothermometer shows that the temperature of the source of the hot water is around $107,5^{\circ} \mathrm{C}$.

The water's chemistry generally indicates the underground course followed through the rocks and the exchange of the chemical elements among them. Indeed, the calcium, bicarbonates and magnesium levels show the exchange between water and rock under the influence of high temperatures. The isotopic values of the waters from Thermopylae, Damasta and Psoroneria show the penetration of the sea in the deep geothermal reservoir (Dotsika et al., 2008).To estimate the temperature in the deep reservoir based on the above mentioned data, the use of the $\mathrm{K}-\mathrm{Mg}$ geothermometer is recommended; and gives probable temperatures of $80-85^{\circ} \mathrm{C}$.

From the analysis and evaluation of all previous data and information, it seems that the geothermal model of the area is the one presented in Figure 4. In this figure, surface water percolates through the raised part of the area which consists of limestones and other formations; and also through faults, cracks and joints and discontinuities into deeper formations. The percolated water is heated and mixed with the existing salt water which penetrated during earlier times, altering the water's tem- 


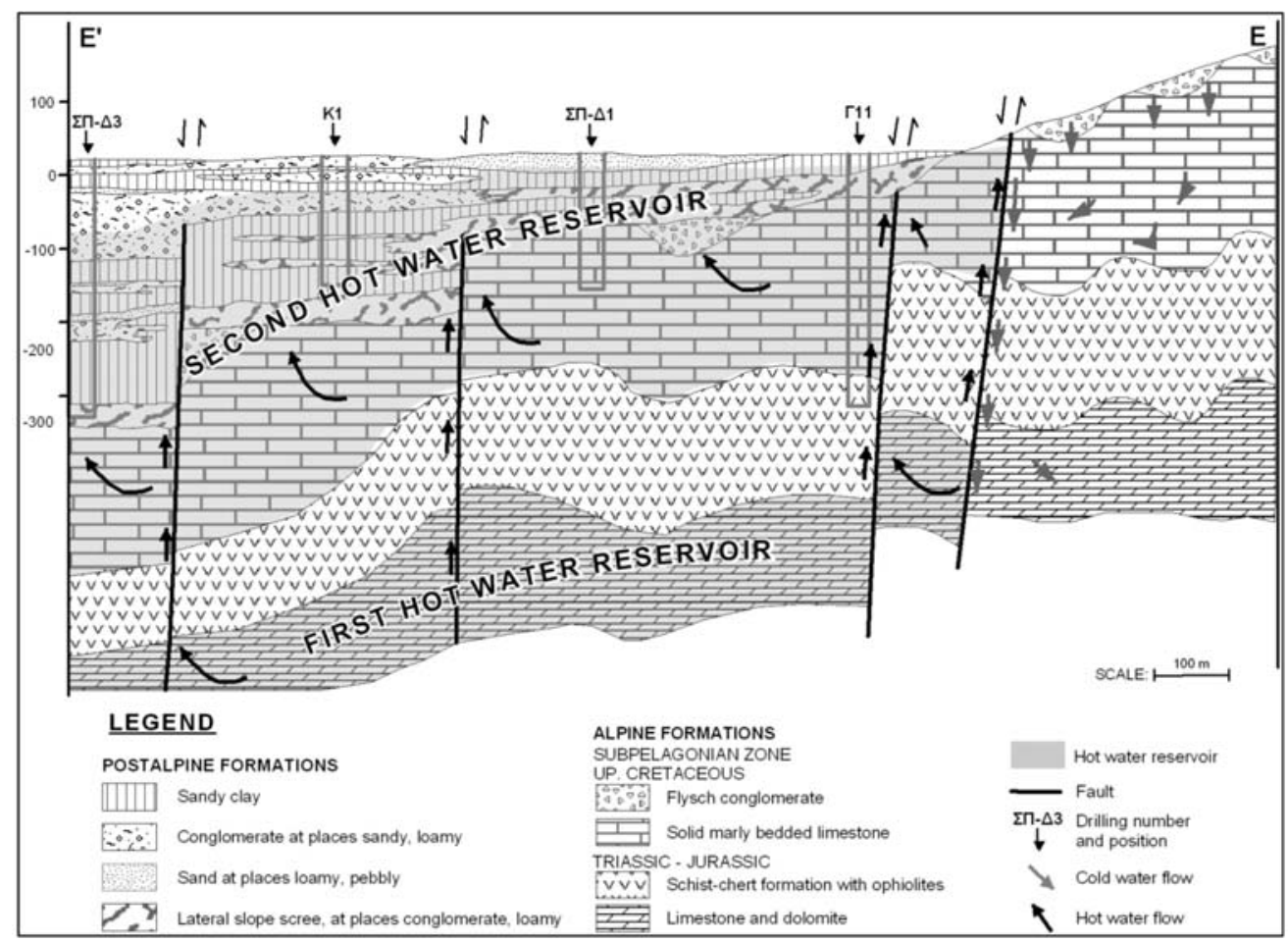

Fig. 4: Geological-Geothermal model of Damasta area.

perature and chemical composition. Finally, through different faults, the water rises again to the surface in the form of hot springs. While rising, part of the water gets trapped in the Triassic-Jurassic limestones \& dolomites, which lie beneath the impermeable cover of the schist-chert formation and the ophiolites. The rest of the water continues to rise and another part of it gets trapped in the Upper Cretaceous limestones that lie below the sediments as well as in the sandy and generally coarsegrained clastic quaternary formations, which are below the fine-grained clastics (clays, sludges) that function as impermeable cover.

From the above mentioned data derives the conclusion that the area has a special geothermal interest with two hot water reservoirs. The first is located in the quaternary sediments and the Upper Cretaceous limestone and is located between just under the surface on the South and $350 \mathrm{~m}$ deep to the North. The second one is located in the Triassic - Jurassic limestone beyond 600m deep and presents the greatest interest in terms of temperature and potentiality.

According to the financial research program in the area of Spercheios and the available resources, it was impossible to explore the deeper reservoir. Because of this, we describe in details only the second -shallower- reservoir.

It appears (Fig. 5) that the most important factor that determines the temperature change, in relation to the depth of the second -shallower- reservoir, are the regional tectonics. High temperatures are occurring just under the surface, on the basement's slopes, and reach $350 \mathrm{~m}$ deep in a relatively short distance due to the faults presence. In drilling $\Sigma \Pi-\Delta 2$ (Fig. 5) was observed a characteristic horst, where in both sides the vertical temperature is sinking because of the faults. 


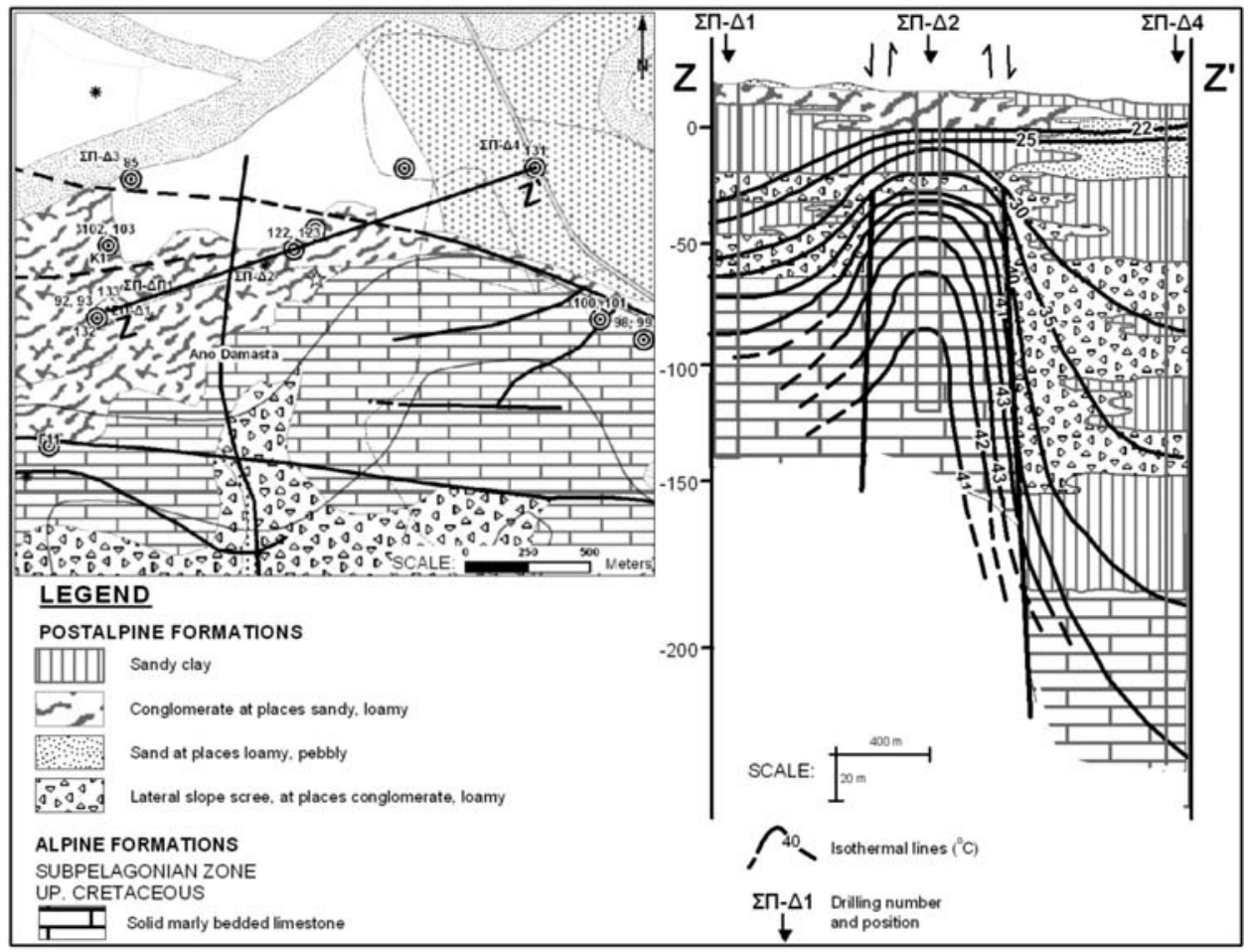

Fig. 5: Geological map of the Damasta area and correlation section Z-Z' with isothermal lines.

Generally, due to the presence of faults, a gradual increase in the depth of high temperatures is observed from the basement (South) towards the basin (from South to North - Northeast). Higher temperatures seem to occur in debris cones above the basement and also inside the basement in the Upper Cretaceous limestone.

The second-shallow reservoir is a hot water table aquifer in the close area of Damasta that has been identified in quaternary basin sediments, especially in coarse-grained clastics, conglomerates, gravel conglomerates, sands, etc., which are often interrupted by clay, as well as in the Upper Cretaceous limestone below quaternary basin sediments. Its main volume and higher temperatures are specified in the Upper Cretaceous limestone, that is fragmented, faulted and karstified, as well as in the overlying limestone debris (breccia, conglomerates, etc.).

The sediments have a standard thickness and expansion because of their fluvial / fluvial-torrential origin. There is a continuous change and movement of river and torrent beds and as a result there is a continuous change in the sediment composition and granulometry.

The high temperatures are starting to appear round about the surface in the southern region, whereas while going north the depth where the hot water table aquifer appears, increases significantly (Fig. 6). This is mostly due to the large and deep faults of NW-SE and N-S direction that exist in the area, and less to those of E-W direction.

In Figure 6 we can see the contour lines of the hot water aquifer's roof, taking into account the temperature of $25^{\circ} \mathrm{C}$. It should be noted that after the edging fault the depth increases significantly to $90 \mathrm{~m}$ absolute altitude in the NE part of the region and to $-130 \mathrm{~m}$ absolute altitude in the NW part, primarily because of the vertical fault of $\mathrm{N}-\mathrm{S}$ direction. 


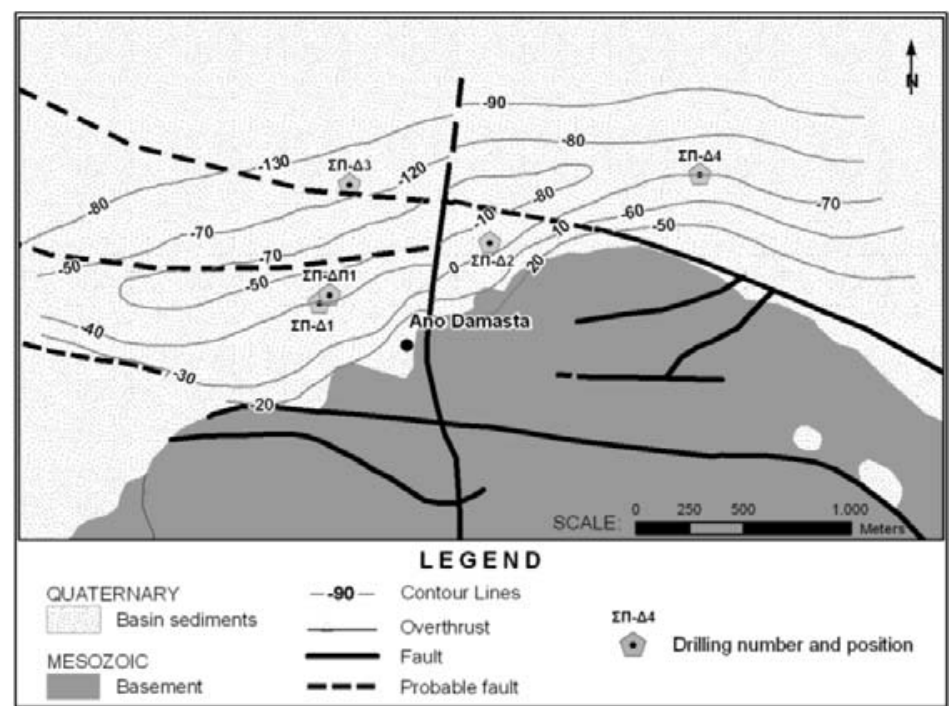

Fig. 6: Map of contour lines for the roof of the hot aquifer $\left(25^{\circ} \mathrm{C}\right)$.

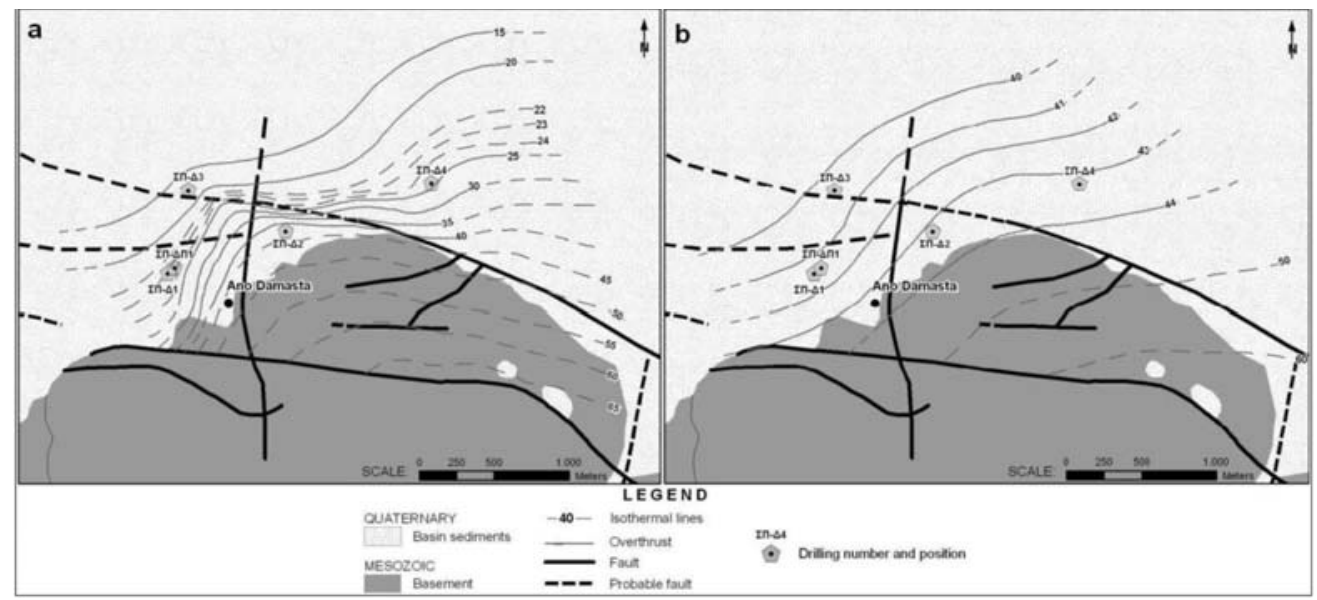

Fig.7: (a): Map of isothermal lines at 50m deep; (b): Map of isothermal lines of the highest temperature.

Taking into account all facts of the close Damasta area and by observing the isothermal lines that were drawn for every 50m depth (Fig. 7a), we see that higher temperatures are found in the southern region and gradually reduce towards North-Northeast. These range from $20-45^{\circ} \mathrm{C}$ depending on the depth of the basin. In the basement, between the two edging faults, although we have no information from drillings, the trend of the lines shows that much higher temperatures of $50-65^{\circ} \mathrm{C}$ are to be expected. We present a map of isothermal lines of the highest temperature that appears in the area (Fig. 7b). It is an area that should be investigated, with future programs, in order to verify or reject the above mentioned theory.

Taking into consideration all the above mentioned factors, the map of the equivalent curves for the average gradient was composed (Fig. 8) for the Damasta region. 


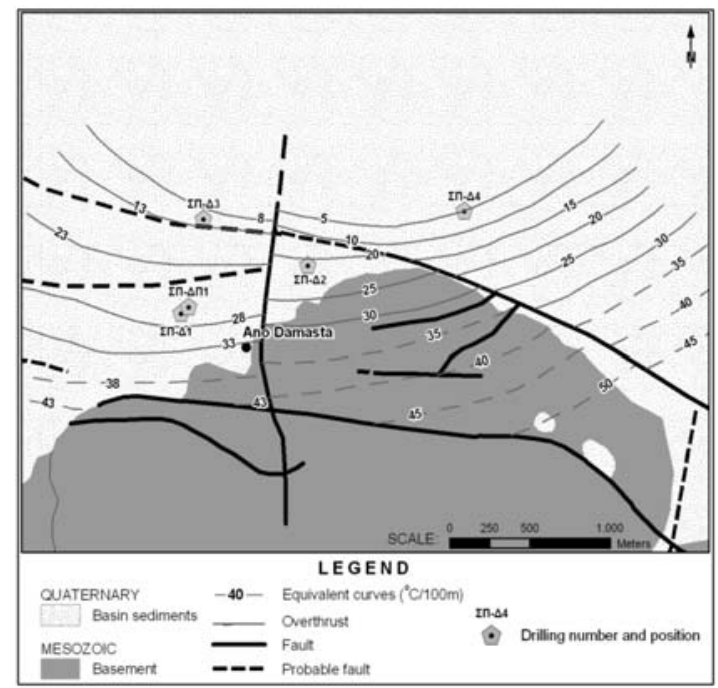

Fig. 8: Map of equivalent curves for the average geothermal gradient.

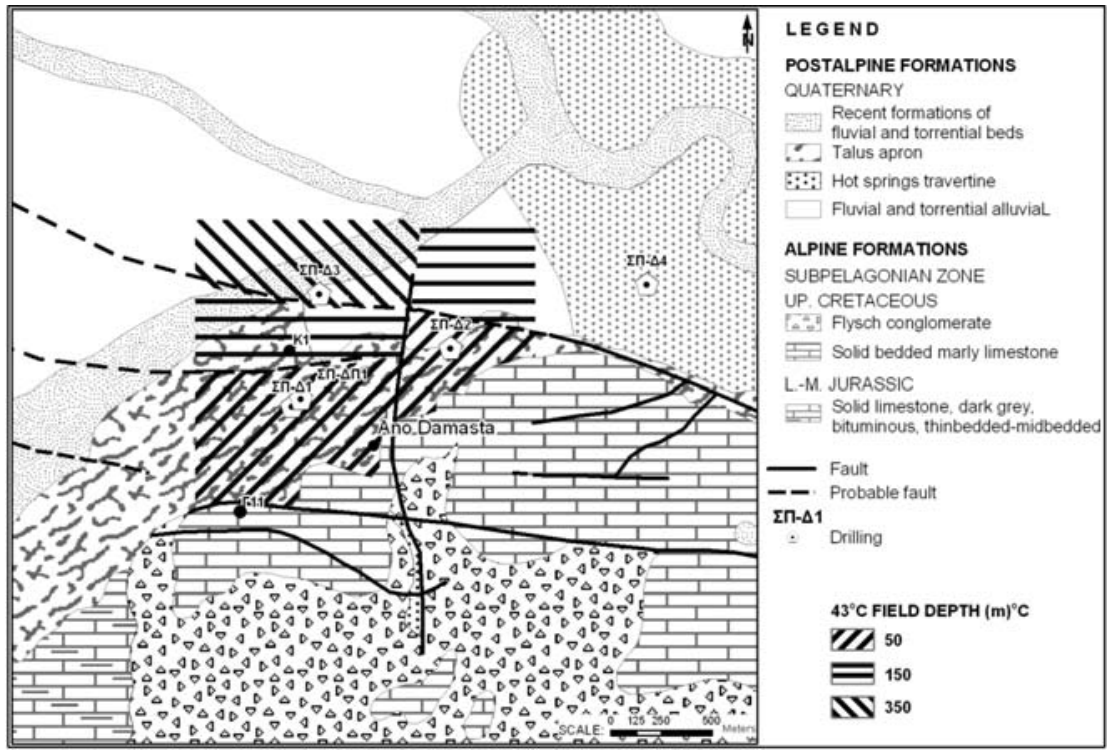

Fig. 9: Map of geothermal fields in Damasta area.

In the map (Fig. 8) the higher values are located South and the lower ones to the North. In the sediments temperature is ranging from $35^{\circ} \mathrm{C} / 100 \mathrm{~m}$ to $5^{\circ} \mathrm{C} / 100 \mathrm{~m}$ and in the basement is estimated at 35 $50^{\circ} \mathrm{C} / 100 \mathrm{~m}$.

After the process and evaluation of all the data and information that the research provided, some geothermal fields, of $43.5^{\circ} \mathrm{C}$ in relation to the depth, have been identified (Fig. 9). This map shows that the most important part, with the higher temperatures and the lower depths, is in the Southern region. Gradually going north the same reservoir deepens due to the tectonics that are observed in the region. 


\section{Results and discussions}

The following new data and results from the presented study can be summarised and further interpreted to the following:

- The thermal anomaly observed in Spercheios is extensive, occupies the entire basin and extends beyond it.

- The surface warm water events occur along the faults observed in the region.

- From the geochemical study of the Damasta area, warm water is salty (sea water), sodic, chloride, neutral to slightly alkaline and non potable.

- The temperature of the hot water source is $107.5^{\circ} \mathrm{C}$ according to the silicate geothermometer and the K-Mg geothermometer while the temperatures of the deep reservoir are $80-85^{\circ} \mathrm{C}$.

- In Damasta area, there are two reservoirs of hot water. The one (second one) is in the quaternary sediments and the Upper Cretaceous limestone and is located between just under the surface on the South and 350m deep to the North. The first and more interesting reservoir, in terms of temperature and capacity, is found in the Triassic-Jurassic limestone at depths exceeding $600 \mathrm{~m}$.

- The geothermal gradient of the second reservoir inside the sediments is ranging from $35^{\circ} \mathrm{C} / 100 \mathrm{~m}$ to $5^{\circ} \mathrm{C} / 100 \mathrm{~m}$ and in the basement is estimated at $35-50^{\circ} \mathrm{C} / 100 \mathrm{~m}$.

- The constant pumping flow to the assigned geothermal field is $115 \mathrm{~m}^{3} / \mathrm{h}$ with a temperature of $43.6^{\circ} \mathrm{C}$, the reservoir has a high permeability and is semi-confined.

There should be a deep drilling research program to identify and explore the deeper reservoir as well as a shallow drilling program to explore the southern part of the study area and enhance the determination of the quantitative and qualitative parameters of the already known reservoir.

Some examples for future exploitation of the geothermal energy in the area when the conditions are favourable are: agricultural applications (greenhouses, etc.), fish farming, desiccation of agricultural products, house heating, and others like indoor swimming pools and SPA therapy that can become an attraction for winter as well as summer tourists.

\section{References}

Dotsika, E., Duriez A., Metaxas A., Karydakis Gr., Varvarousis G., Marlin C., 2008. Isotopic and geochemical study of hot water in Spercheios basin, Athens, 111.

Dounas, G.A., et. al., 1978. Hydrogeological research of Sperchios basin - annex - inventory of water points, Hydrological and hydrogeological researches, N.26, I.G.M.E., Athens, p.105

Garagunis, C., 1976. Geothermal areas in the Maliac Gulf region in Greece. Proceedings of the Int. Congress on Thermal Waters, Geothermal Energy and Volcanism of the Mediterranean Area, vol. 1, Athens p.241-274

Marinos, G., Anastopoulos J., Maratos G., Melidonis N., Andronopoulos B., 1963. Geological map of Greece, Stilis sheet, scale 1:50.000, I.G.M.E., Athens.

Marinos, G., Papastamatiou J., Maratos G., Melidonis N., Andronopoulos B., Tataris A., Betoulis D., Katsikatsos G., Maragoudakis N., Lalechos N., 1967. Geological map of Greece, Lamia sheet, scale 1:50.000, I.G.M.E., Athens.

Metaxas, A., Varvarousis G., Karydakis Gr., 2008. Geothermical research of Spercheios basin, I.G.M.E., Athens, p.193.

Stamatakis, M., 1987. Boron distribution in hot springs, volcanic emaciations, marine evaporates and sedimentary rocks of Cenozoic age in Greece, phd dissertation, University of Athens, 459pp. 